\title{
THE NATURE AND PURPOSE OF THE GENERAL MEETINGS OF THE SUPRANATIONAL ECONOMIC ASSOCIATIONS IN THE EUROPEAN UNION
}

\author{
Asen VODENICHAROV \\ „Neofit Rilski” South-West University, Blagoevgrad, Bulgaria \\ asenvodenicharov@mail.bg
}

\begin{abstract}
The general meeting is the supreme body of the European company as well as of the other European entities for economic association. It is a body forming and expressing the intention of a company. It is a specific forum for the free and voluntary expression of the intentions of its individual participants. The intentions can be expressed by an individual or a group, but they always express a specific attitude. A meeting collects, as a "funnel", the expressed concerns, the suggestions supporting or rejecting the expressed theses, etc., with regard to the discussed issues. This forms the common will of the participating parties. The general meeting of shareholders is a legally established body of an European company. In view of its structure, the general meeting of shareholders is a collective body. It includes all shareholders entitled to vote. Therefore, it can be defined as a college because it approves all decisions as a college at in-person meetings or in absentia. Thus the meeting in question is the only legal means by which shareholders may exercise moral management rights: participation in management, right to vote, active and passive right to elect and be elected to the board of directors, management or supervisory board, etc. The legal framework of the general meeting of shareholders has hybrid nature.
\end{abstract}

Keywords: general meeting, European Economic Interest Grouping (EEIG), European company (SE), European Cooperative Society (SCE)

1. The harmonious development of the European Union's single market has led to the creation of a new legal framework which facilitates the adaptation of the natural persons, companies, firms and other legal bodies' activities to the economic conditions of the Community. To the achievement of the abovementioned objective, as well as towards addressing the legal, fiscal or psychological difficulties has required the creation of an appropriate Community legal instrument in the form of a European Economic Interest Grouping (EEIG) [1], European company (SE) [2] and European Cooperative Society (SCE) [3].

2. The general meeting (assemblée générale) occupies an especially significant place in the organizational system of the bodies of cross-border European companies for economic grouping.

It is an inherent element of every corporate entity. Its existence in the business segment of social practice is manifested in the civil and commercial legislation of all countries. Its legal regulation is harmonized to a considerable extent in the Member States of the European Union. The existence of this body is also provided for organizational and legal structures active in other areas of public life in our country [4].

The general meeting is the supreme body of the European company as well as of the other European entities for economic association. Its place in their hierarchical organization chart is determined by its broad competence. The objective content of its powers includes resolution of key 
issues concerning the development of the company, the amendment and supplementation of the statutes, the increase and decrease of capital, the reorganization and winding up of the company, etc. It legal and regulatory base has also been enhanced. The general meeting of the European company has as its legal basis not only Regulation (EC) № 2157, but also the legislation of the Member State in which the registered office of the company is located according to its constituent act adopted in compliance with Council Directive 2001/86/EC of 8 October 2001 supplementing the Statute for a European company with regard to the involvement of employees [5]. This regulatory framework is to include its competence to resolve the issues assigned to the general meeting of a public limited liability company according to the existing legal regulations in the respective country. This is a particularly relevant for the further harmonization and coordination of the national laws of Member States.

The general meeting is a body forming and expressing the intention of a company. It is a specific forum for the free and voluntary expression of the intentions of its individual participants. The intentions can be expressed by an individual or a group, but they always express a specific attitude. A meeting collects, as a "funnel", the expressed concerns, the suggestions supporting or rejecting the expressed theses, etc., with regard to the discussed issues. This forms the common will of the participating parties. It is finds a legal expression in the decisions that are adopted. The organization of the implementation of the adopted decisions resulting from the common will of the shareholders participating in the meeting is to be implemented by the executive bodies formed as a result of that will - the board of directors in a one-tier system of governance and a management board and a supervisory board in a two-tier system. These company bodies take the necessary legal actions to achieve the desired legal and material and technical goals.

It should be noted that the general meeting should not be equated with the European company itself. These are two legal constructions. The general meeting is a body of the company. In practice, the general is formed by all shareholders. Therefore we can state that the main body is actually constituted by the shareholders. To support this thesis we should note the fact that there is a legal possibility to adopt decisions in absence, that is without holding an in-person meeting. This option is not expressly provided for in Regulation (EC) № 2157/2001. The reference in Article 52 to national laws, however, creates the necessary legal possibility to make decisions in absence since most laws in the field of civil and commercial law in the the Member States have regulated this hypothesis. Regulation (EEC) № 2137/85 on the European Economic Interest Grouping stands out in this respect. It states in Article 17, point 4 that "On the initiative of a manager or at the request of a member, the manager or managers must arrange for the members to be consulted so that the latter can take a decision.

The general meeting of shareholders is a legally established body of a European company. That is expressly stated in Regulation (EC) № 2157/2001. Thus a company has strong legal stability. Its removal as a legal body in the structure may only take place by amending the Community act. This is a lengthy process. The legislative practice of European lawmakers shows that the adoption of a new regulation to amend or supplement an existing act is four - five years. This process is even longer if a new regulation is prepared to govern the same public relations and to repeal the previous regulation of the Council. Moreover, it should be pointed out that this process takes place outside the European company. The rulemaking procedure will evolve under the two hypotheses of Article 290 
and Article 291 of the Treaty on the Functioning of the European Union.

The general meeting is a mandatory body of a company. It is envisaged not only in Regulation (EC) № 2157/2001 for a European company, but also for a European Cooperative Society in Regulation (EC) № 1435/2003. In the latter Community act, section four, titled General Meeting deals consistently with its powers, conduct, holding, form and period for convening, additions to the agenda, attendance and proxies, voting rights, right to information and taking decisions, etc. (Article 52-63). The statutes of the general meetings of the discussed two new European companies - European private company and European single-member private limited liability company - are objects of the draft documents for their regulation at Union level.

The regulatory framework of the European Economic Interest Grouping is different in the discussed area. Although Regulation (EEC) № 2137/85 settles its body structure, it does not indicate an organ named "General Meeting". By contrast, it is stated that "the members act collectively" (Article 16). We consider that despite the absence of legal and technical identity with the other two Community acts, the intention-forming and intentionexpressing nature of the members of the grouping remains unchanged. The consistent interpretation of this provision in conjunction with Article 17 shows that this is the only collective body of the grouping [6]. It is assigned a decisionmaking role in relation to all significant issues such as alteration in the objects of the grouping; the transfer of the official address of the grouping; the number of votes allotted to each member; appointment and removal of the manager; alteration in the conditions for the taking of decisions; unanimous authorization for assignment of participation in the grouping, or a proportion thereof either to another member or to a third party; unanimous decision to admit new members, etc. (Article 14(1), Article 17, point 2, Article 19(3), Article 22(1), Article 26(1), etc.).

In practice, the general meeting of a European company and a European Cooperative Society is composed of their members. Taking part in the meeting, they also act collectively although this is not stated explicitly. Regulation (EC) № 2137/85 outlines the range of issues requiring collective discussion and resolution by reaching a common intention. The regulation states that each member has one vote, defines the issues which require unanimity, etc. For that reason a large number of authors determined that since "the members act collectively" then they are, in terms of structure, the supreme body of a European Economic Interest Grouping [7].

In view of its structure, the general meeting of shareholders is a collective body. It includes all shareholders entitled to vote. Therefore, it can be defined as a college because it approves all decisions as a college at in-person meetings or in absentia. Thus the meeting in question is the only legal means by which shareholders may exercise moral management rights: participation in management, right to vote, active and passive right to elect and be elected to the board of directors, management or supervisory board, etc.

3. The legal framework of the general meeting of shareholders has hybrid nature. Regulation (EC) № 2157/2001 contains imperative provisions on the organization and conduct of the general meeting (Article 52-60). They regulate only the main elements of its status. At the same time the Community act provides for subsidiary application of the national law on public limited-liability companies ("SE") of the Member State where the company's registered office is situated and the Statute of specific European company (Article 52, b) and Article 53). Special attention is placed on the compliance with the domestic law of the country in relation 
to the transposition of Council Directive 2001/86/EC of 8 October 2001 supplementing the Statute for a European company with regard to the involvement of employees.

According to Regulation (EC) № 2157/2001 the organization and conduct of general meetings together with voting procedures shall be governed by the law applicable to public limited-liability companies in the Member State in which the European public limited-liability company's registered office is situated. The company law of the EU Member States in this area is very similar.

The general meeting consists of all shareholders pursuant to an imperative provision of the Community act (Article 52). Therefore, they are members of the meeting ex lege and their exclusion from it is inadmissible. There is a legal possibility for two categories of persons who are not qualified as a "shareholder" to participate in its work but without right to vote. They have the right to an advisory vote, i.e. their vote is not included in the formation and expression of the common will of the general meeting. These participants can express their opinions, support or criticize proposals, ask questions, etc., but may not participate in the approval of decisions. The first group consists of members of the board of directors, respectively the supervisory and management board where they are not shareholders. Their participation is justified because their involvement in the operational management of the business makes them well acquainted with the current problems of the development of the company, the practical guidance for improving competitiveness, the automation of operations, the application of innovations, etc., and they can express their opinions. The second group includes representatives of workers and employees of the company. Their involvement in the supreme body becomes the basis of Directive 2001/86/EC which was transposed in all Member States. The number of employees in the company which limits the participation of their representatives in the general meeting ranges from 50 to 450 in the individual Member States [8]. Their participation enables them to draw the attention of shareholders to issues related to the more active involvement of the employees in the more efficient resolution of production issues, improvement of the social climate and social responsibility, etc.

A participant in a general meeting may be represented. They may appoint as a proxy not only another shareholder but also someone who is external to the company. In such cases the authorization requires a notary's attestation. That requirement is the same both for individuals and legal entities. The authorization for representation of legal entities must be signed by the representative of the organization. The absence of the latter's signature will void the issued document and it will not have any legal consequences.

\section{References}

[1] Council Regulation (EEC) No 2137/85 of 25 July 1985 on the European Economic Interest Grouping (EEIG), OJ L 199, 31.7.1985, p. 1-9.

[2] Council Regulation (EC) No 2157/2001 of 8 October 2001 on the Statute for a European company (SE), OJ L 294, 10.11.2001, p. 1-21.

[3] Council Regulation (EC) No 1435/2003 of 22 July 2003 on the Statute for European Cooperative Society (SCE), OJ L 207, 18.08.2003, p.1-24.

[4] Direct Citizen Participation in State and Local Government Act - section IV, Articles 5464 (Promulgated, State Gazette (SG) 44 of 12.06.2009, amended SG 56 of 24.07.2015); Condominium Ownership Management Act - section II, Articles 18 - 25 (Promulgated, SG 6 of 23.01.2009, amended SG ДВ, 43 of 7.06.2016); Non-Profit Legal Entities Act chapter II, section I, Article 23-29 (Promulgated, SG $\underline{81}$ of 6.10.2000, amended SG 103 
of 27.12.2016; Community Centers Act - Article 9-a, Articles 11-17 (Promulgated, SG 89 of 22.10.1996, amended SG 74 of 20.09.2016, in effect from 1.01.2018); Act on the Association of Veterinary Professionals in Bulgaria - section 2, Articles 7-12, section 3, Articles 16-20 (Promulgated, SG 84 of 19.10.2007, amended SG 14 of 19.02.2016); Irrigation Associations Act - section III, Articles 25-31, section IV, Articles 34-39 (Promulgated, SG 34 of 6.04.2001, amended and supplemented SG 54 of 15.07.2016 ) etc.

[5] Council Directive 2001/86/EC of 8 October 2001 supplementing the Statute for a European company with regard to the involvement of employees, Official Journal of the European Union, Special edition in Bulgarian: Chapter 6, Volume 4 pages 134 - 144 was transposed in Bulgarian legislation with the Law on informing and consulting with workers and employees in multinational companies, enterprise groups and European companies (Promulgated, SG 57 of 14 July 2006, amended SG 26 of 29 March 2011, amended SG 82 of 21 October 2011).

[6] See detailed study - Mateeva-Stoyanova, Ek., European grouping based on a common economic interest and Bulgarian company law. S., Ciela, 2000, 735 c.

[7] Kohlhosse,H, A.Raddatz, Europäischen wirtschaftlichen Interessenvereinigung (EWIV), Berlin,JA,1989;.Guillemin, J-Fr., Le GEIE, un instrumente de la coopération frontalière, RD, 1989, p. 451; Hamilton, B., European Economic Community, Los Angeles, 2003, p. 58.

[8] It is stated in Article 220(3) of the Commercial Law that where a company has more than 50 employees, they shall be represented in the general meeting by one person with a consultative vote. Similar provisions exist also in the Greek legislation - Гí

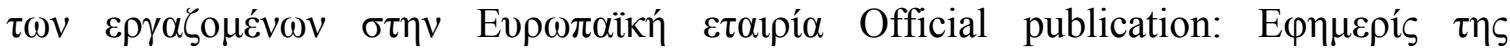

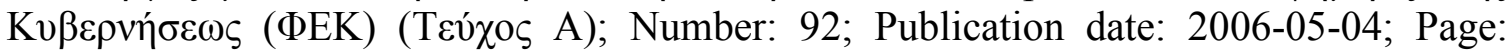
00918-00924, in the Spanish legislation - LEY 31/2006, de 18 de octubre, sobre implicación de los trabajadores en las sociedades anónimas y cooperativas europeas, Official publication: Boletín Oficial del Estado ( B.O.E ); Number: 250/2006; Publication date: 2006-10-19; Page: 36302-36317, Romanian legislation - Lege privind constituirea, organizarea şi funcţionarea comitetului european de întreprindere Official publication: Monitorul Oficial al României; Number: 628; Publication date: 2005-07-19; Page: 00001-00007 etc. 